\title{
MODEL PENDIDIKAN KARAKTER DALAM KELUARGA
}

\author{
Ade Kartini \\ MAS Al-Choeriyyah Cibeas Tasikmalaya \\ akartini76@gmail.com \\ Asep Maulana \\ Institut Agama Islam Negeri Jember \\ asepmaulana8464@gmail.com
}

\begin{abstract}
Cultivating character in children is highly recommended to be formed from an early age. Because early childhood is a critical period that will determine children's attitudes and behavior in the future. Parents need to instill moral values as the basis of religious norms and social norms adhered to by the family. Parents' upbringing for their children determines and influences the child's personality and behavior. Children will be good or not all depending on the parenting style of the parents in the family. Thus, a comprebensive character education model in the family is very necessary and important to understand and actualize. This library research is conducted through documentation study and qualitative data analysis. The findings of the research state that character education that has high values must be designed in an educational model. Goal setting is the first thing to do. These goals will guide where this program is directed. To fulfill this, a character education development model in the family is made through several relevant approaches, methods and strategies. and women so that they can change according to different times. gender that has been outlined by nature.
\end{abstract}

\section{Keywords: Model, Character Education, Family}

\section{Abstrak}

Penanaman karakter pada anak sangat dianjurkan untuk dibentuk sejak dini. Karena usia dini merupakan masa kritis yang akan menentukan sikap dan perilaku anak di masa yang akan datang. Orang tua perlu menanamkan nilai-nilai moral sebagai dasar dari norma agama dan norma sosial yang dianut oleh keluarga. Pola asuh orang tua terhadap anak- 


\section{Ade Kartini, Asep Maulana}

anaknya sangat menentukan dan memengaruhi kepribadian serta perilaku anak. Anak akan menjadi baik atau tidak semua tergantung dari pola asuh orang tua dalam keluarga. Dengan demikian model pendidikan karakter dalam keluarga yang komprehensif sangat diperlukan dan penting untuk dipahami dan dapat diaktualisasikan. Penelitian kepustakaan ini dilakukan melalui studi dokumentasi dan analisis data kualitatif. Temuan hasil penelitian menyatakan bahwa pendidikan karakter yang mempunyai nilai yang luhur haruslah dirancang dalam sebuah model pendidikan. Penetapan tujuan adalah hal pertama yang harus dilakukan. Tujuan ini akan menuntun program ke arah yang diinginkan. Untuk memenuhi hal tersebut dibuatlah sebuah model pengembangan pendidikan karakter dalam keluarga melalui beberapa pendekatan, metode, dan strategi yang relevan.

\section{Kata Kunci : Model, Pendidikan Karakter, Keluarga}

\section{Pendahuluan}

Keluarga merupakan ujung tombak dalam pembentukan pribadi anak karena keluarga mempunyai peranan paling penting dalam pendidikan anak. Keluarga adalah tempat tumbuh kembang anak mulai dari lahir hingga dewasa. Oleh sebab itu, pendidikan dalam keluarga harus menjadi perhatian yang utama. Peranan keluarga mengemban kepentingan yang besar dalam pendidikan anak. Terlebih di usia anak dalam tahap balita. Pada masa tersebut, apa yang ditanamkan dalam diri anak akan sangat membekas sehingga tidak mudah dan berubah.

Penanaman karakter pada anak sangat dianjurkan untuk dibentuk sejak dini. Hal ini disebabkan karena usia dini merupakan masa kritis yang akan menentukan sikap dan perilaku anak di masa yang akan datang. Orang tua perlu menanamkan nilai-nilai moral sebagai dasar dari norma agama dan norma sosial yang dianut oleh keluarga. Pola asuh orang tua terhadap anakanaknya sangat menentukan dan memengaruhi kepribadian serta perilaku anak. Anak akan menjadi 
Vol. 13, No. 2, Oktober 2020

p-ISSN:2086 -0749

e-ISSN:2654-4784

baik atau tidak semua tergantung dari pola asuh orang tua dalam keluarga.

Pembentukan karakter pada usia dewasa akan sulit dilakukan jika anak tidak dididik secara benar pada usia dini. Anak yang memiliki karakter kelak diharapkan dapat melakukan pengendalian diri sehingga tidak mudah dipengaruhi orang lain, dapat menahan emosi, tidak mudah frustasi, dan mampu menghadapi kegagalan. Makalah ini disusun guna memberikan gambaran singkat bagaimana model pengembangan pendidikan karakter dalam keluarga. Penelitian ini meliputi hal yang berkenaan dengan model pengembangan pendidikan karakter dalam keluarga. Pembahasan tidak sampai pada ranah implementasi dan tataran praktis.

Adapun rumusan masalah dalam penelitian ini antara lain: 1)
Bagaimanakah yang dimaksud dengan karakter?, 2) Bagaimanakah yang dimaksud dengan pendidikan karakter?, 3) Bagaimanakah yang dimaksud dengan pendidikan karakter dalam keluarga?, dan 4) Bagaimanakah model pengembangan pendidikan karakter dalam keluarga?. Sementara itu, tujuan dan kegunaan penelitian ini adalah untuk memberikan gambaran umum dan sekilas mengenai pendidikan karakter dalam keluarga dan model pengembangannya. Penelitian kepustakaan ini dilakukan melalui studi dokumentasi dan analisis data kualitatif

\section{Pembahasan}

\section{Pengertian Karakter}

Pengertian karakter menurut Pusat Bahasa Depdiknas adalah "bawaan, hati, jiwa, kepribadian, budi pekerti, perilaku, personalitas, sifat, tabiat, 


\section{Ade Kartini, Asep Maulana}

temperamen, watak". Adapun

berkarakter adalah berkepribadian, berperilaku, bersifat, bertabiat, dan berwatak.

Karakter berasal dari bahasa Yunani yang berarti "to mark" yang berarti menandai dan memfokuskan bagaimana mengaplikasikan nilai kebaikan dalam bentuk tindakan atau tingkah laku, sehingga orang yang tidak jujur, kejam, rakus, dan perilaku jelek lainnya dikatakan orang yang berkarakter jelek, begitu pun sebaliknya.

Dalam bahasa Inggris, charater, memiliki arti: watak, karakter, sifat; peran; dan huruf. Karakter juga dapat diartikan mental or moral qualities that make a thing what it is different from others, atau all those qualities that make a thing different from others. Karakter juga berarti agregat fitur dan ciri-ciri yang membentuk sifat individu dari beberapa orang atau hal. Dengan demikian, karakter adalah sifatsifat kejiwaan, akhlak, atau budi pekerti yang membedakan seseorang dengan yang lain; tabiat; watak, berkarakter: mempunyai tabiat, mempunyai kepribadian. ${ }^{1}$

Menurut Simon Philips dalam Buku Refleksi Karakter Bangsa, karakter adalah kumpulan tata nilai yang menuju pada suatu sistem, yang melandasi pemikiran, sikap, dan perilaku yang ditampilkan. ${ }^{2}$ Koesoema A menyatakan bahwa karakter sama dengan kepribadian. Kepribadian dianggap sebagai "ciri atau karakteristik atau gaya atau sifat khas dari diri seseorang yang bersumber dan bentukan-bentukan yang diterima dari lingkungan, misalnya keluarga pada masa kecil dan juga bawaan seseorang sejak lahir". Prof. Suyanto, Ph.D menyatakan bahwa karakter adalah cara berpikir dan berperilaku yang menjadi ciri khas

\footnotetext{
1 Aan Hasanah, Pendidikan Karakter Berperspektif Islam, (Bandung: Insan Komunika, 2013), cet. II, hlm. 40-41

${ }^{2}$ Masnur Muslich, Pendidikan Karakter Menjawab Tantangan Krisis Multidimensional, (Jakarta: Bumi Aksara, 2014), cet. IV, hlm. 70
} 
Vol. 13, No. 2, Oktober 2020

p-ISSN:2086 -0749

e-ISSN:2654-4784

tiap individu untuk hidup dan bekerjasama, baik dalam lingkup keluarga, masyarakat, bangsa dan negara. Individu yang berkarakter baik adalah individu yang bisa membuat keputusan dan siap mempertanggungjawabkan tiap akibat dari keputusan yang ia buat. Menurut Victoria Neufeld \& David B. Guralnik adalah 'distinctive trait, distinctive quality, moral strenght, the pattern of behavior found in an individual of group'. Dari berbagai pendapat di atas dapat disimpulkan bahwa karakter itu berkaitan dengan kekuatan moral, berkonotasi 'positif', bukan netral. Jadi, 'orang berkarakter' adalah orang yang mempunyai kualitas moral (tertentu) positif. ${ }^{3}$

Imam al-Ghazali menganggap bahwa karakter lebih dekat dengan akhlak, yakni sikap dan Karakter, hlm. 71 perbuatan yang telah menyatu dalam diri manusia sehingga muncul secara spontan ketika berinteraksi dengan lingkungan. Keutamaan memiliki akhlak atau karakter mulia dinyatakan Rasulullah SAW dalam beberapa hadis berikut yang berisi tentang ${ }^{4}$ :

a. Mukmin yang baik keimanannya adalah mukmin yang memiliki akhlak yang palin baik (HR. Abu Daud);

b. Orang yang paling akhlaknya berada dekat dengan Rasulullah saw. pada hari kiamat (HR. AtTirmidzi);

c. Budi pekerti yang baik adalah kebajikan (HR. Muslim);

d. Akhlak yang baik memiliki timbangan yang berat di akhirat (HR. At-Tirmidzi dan HR. Ahmad).

4 Ridwan Abdullah Sani dan Muhammad Kadri, Pendidikan Karakter Mengembangkan Karakter Anak yang Islami, (Jakarta: Bumi Aksara, 2016), hlm. 44-47 


\section{Ade Kartini, Asep Maulana}

2. Pengertian Pendidikan

Karakter

Karakter lebih bersifat subjektif, sebab berkaitan dengan struktur antropologis manusia dan tindakannya dalam memaknai kebebasannya sehingga ia mengukuhkan keunikannya berhadapan dengan orang lain. Sementara pendidikan senantiasa berkaitan dengan dimensi sosialitas manusia. Hal ini karena sejak lahir manusia telah membutuhkan kehadiran orang lain dalam menopang hidupnya. Pendidikan adalah proses internalisasi budaya ke dalam diri seseorang dan masyarakat sehingga membuat orang dan masyarakat jadi beradab. Jadi, pendidikan merupakan sarana strategis dalam pembentukan karakter. Hal ini juga diperkuat oleh pendapat Ki Supriyoko yang menyatakan bahwa pendidikan adalah sarana strategis untuk meningkatkan kualitas manusia. Pendidikan yang bertujuan melahirkan insan cerdas dan berkarakter kuat itu, juga pernah dikatakan Dr. Martin Luther King, yakni; intellegence plus character that is the goal of true education (kecerdasan yang berkarakter adalah tujuan akhir pendidikan yang sebenarnya). ${ }^{5}$ Oleh karena itu pendidikan karakter merupakan keseluruhan dinamika relasional antarpribadi dengan berbagai macam dimensi, baik dari dalam maupun dari luar dirinya. Agar pribadi itu semakin dapat menghayati kebebasannya sehingga ia dapat semakin bertanggungjawab atas pertumbuhan dirinya sendiri sebagai pribadi dan perkembangan orang lain dalam hidup mereka. Secara singkat, pendidikan karakter bisa diartikan sebagai sebuah bantuan sosial agar individu itu dapat bertumbuh dalam menghayati kebebasannya dalam hidup bersama dengan orang lain dalam dunia. Pendidikan karakter bertujuan memben-

${ }^{5}$ Masnur Muslich, Pendidikan Karakter, hlm. 75 
Vol. 13, No. 2, Oktober 2020

p-ISSN:2086 -0749

e-ISSN:2654-4784

tuk setiap pribadi menjadi insan yang berkeutamaan. ${ }^{6}$

Pendidikan karakter memersyaratkan adanya pendidikan moral dan pendidikan nilai. Pendidikan moral menjadi agenda utama pendidikan karakter. Kelak seorang yang mampu mengambil keputusan dan bertindak secara bebas dalam kerangka kehidupan pribadi maupun komunitas akan semakin mengukuhkan keberadaan dirinya sebagai manusia yang bermoral. Ruang lingkup pendidikan karakter bukan hanya sekedar berkaitan dengan tata nilai moral, melainkan berkaitan dengan tata nilai dalam masyarakat. Pendidikan karakter mengandalkan adanya pendidikan nilai agar individu yang ada dalam masyarakat itu dapat berhubungan

6 Zainal Aqib, Pendidikan Karakter Membangun Perilaku Positif Anak Bangsa, (Bandung: Yrama Widya, 2014), cet. II, hlm. 38 dengan baik, hal itu membantu individu lain dalam menghayati kebebasannya. $^{7}$

\section{Pendidikan Karakter da- lam Keluarga}

Keluarga adalah kelompok kecil yang memiliki pemimpin dan anggota, mempunyai pembagian tugas dan kerja, serta hak dan kewajiban bagi masing-masing anggotanya. Keluarga adalah tempat pertama dan yang utama di mana anak-anak belajar. Dari keluarga, mereka mempelajari sifat-keyakinan, sifat-sifat mulia, komunikasi dan interaksi sosial, serta keterampilan hidup.

Ada beberapa pengertian keluarga, baik dengan makna yang sempit maupun dengan makna yang lebih luas.

a. Dalam kamus Bahasa Indonesia Modern secara harfiah

7 Zainal Aqib, Pendidikan Karakter, hlm. 49 


\section{Ade Kartini, Asep Maulana}

keluarga berarti sanak

saudara: kaum kerabat, orang seisi rumah, anak bini;

b. Dalam kamus Oxford Learner's Pocket Dictionary, keluarga berasal dari family yang berarti:

1) Group consisting of one two parents and their children (kelompok yang terdiri dari satu atau dua orang tua dan anakanak mereka); 2) Group consisting of one or two parents, their cbildren, and close relations (kelompok yang terdiri dari satu atau dua orang tua, anak-anak mereka, dan kerabat-kerabat dekat); 3) All the people descended from the same ancestor (semua keturunan dari nenek moyang yang sama).

Orang tua merupakan pendidik pertama dan utama bagi anak-anak mereka karena dari orang tua anak-anak pertama menerima pendidikan. Dengan demikian, bentuk pertama dari pendidikan terdapat dalam kehidupan keluarga. Pendidikan da- lam keluarga juga disebut sebagai lembaga pendidikan informal. Dijelaskan dalam Pasal 27 bahwa kegiatan pendidikan informal yang dilakukan oleh keluarga dan lingkungan terbentuk kegiatan belajar secara mandiri.

Keluarga sebagai lingkungan pendidikan yang pertama sangat berpengaruh dalam membentuk pola kepribadian anak. Di dalam keluarga anak pertama kali berkenalan dengan nilai dan norma. Pendidikan keluarga memberikan pengetahuan dan keterampilan dasar, agama dan kepercayaan, nilai-nilai moral, norma sosial, dan pandangan hidup yang diperlukan anak. Mengenai hal ini Allah berfirman dalam surat al-Tahrìm ayat 6 yang berbunyi:

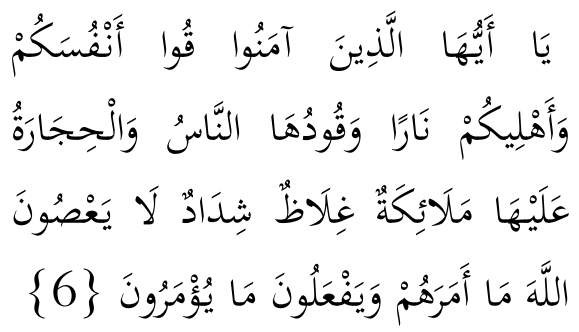


Vol. 13, No. 2, Oktober 2020

p-ISSN:2086 -0749

e-ISSN:2654-4784

Artinya: Hai orang-orang yang beriman, pelibaralah dirimu dan keluargamu dari api neraka yang bahan bakarnya adalah manusia dan batu; penjaganya malaikatmalaikat yang kasar, keras, dan tidak mendurbakai Allab terbadap apa yang diperintabkan-Nya kepada mereka dan selalu mengerjakan apa yang diperintabkan.

Ayat di atas mengindikasikan bahwa orang tua yang beriman hendaknya menjaga diri dan keluarganya dari api neraka. Maksud dari ayat ini adalah agar para orang tua menyiapkan diri dan anak-anaknya serta mengingatkan mereka juga kerabat terdekat untuk selalu menjalankan perintah-Nya dan menjauhi semua larangan-Nya, tentu akan menjauhkan orang tua dan anak-anak yang beriman dari ancaman api neraka. ${ }^{8}$

${ }^{8}$ Helmawati, Pendidikan Keluarga Teoritis dan Praktis, (Bandung: Remaja Rosdakarya, 2014), hlm. 51
Proses pendidikan karakter merupakan internalisasi nilai dalam sebuah tindakan dan perilaku seorang individu. Nilai inilah kemudian yang akan mengikat dan membungkus perilaku menjadi sebuah karakter yang menjadi. Di dalam ruang lingkup keluarga pendidikan karakter pun harus ditransfromasi dengan sejumlah nilai. Setidaknya ada empat nilai yang ditanamkan dalam keluarga.

Pertama, nilai kerukunan. Jika dalam keluarga sudah ditanamkan nilai-nilai kerukunan sejak dini, anak akan terbiasa menyelesaikan masalah dengan musyawarah.

Kedua, nilai ketakwaan dan keimanan. Seseorang yang memiliki ketakwaan dan keimanan yang benar akan mewujudkannya dalam perilaku diri.

Ketiga, nilai toleransi. Maksud toleransi di sini adalah ada 


\section{Ade Kartini, Asep Maulana}

kemauan memperhatikan sesamanya. Dalam keluarga nilai toleransi ini dapat ditanamkan melalui proses saling memerhatikan dan saling memahami.

Keempat, nilai budaya sehat. Kebiasaaan sehat yang dimaksud di sini adalah kebiasaan-kebiasaan hidup yang sehat dan mengarah pada pembangunan diri yang lebih baik.

Gambar. 2.1

Empat nilai yang dapat

ditanamkan dalam keluarga

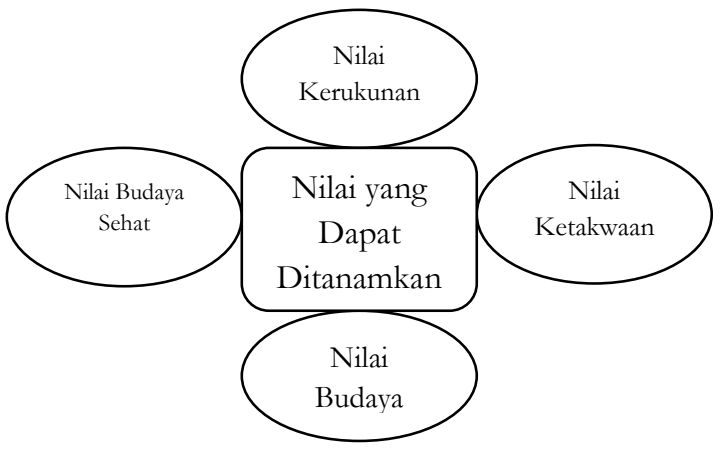

Proses pendidikan dalam keluarga nilai-nilai tersebut di atas disampaikan dalam banyak metode yang dapat digunakan dalam mendidik anak. Pada zaman

9 Masnur Muslich, Pendidikan Karakter, hlm. 93 yang mulai kehilangan sifat kemanusiaannya, ada beberapa metode yang mampu mengembalikan nilai-nilai kemanusiaan manusia agar dapat menjadi lebih manusiawi. Metode pendidikan yang sebaiknya dilaksanakan dalam keluarga, di antaranya sebagai berikut:

\section{1) Metode Keteladanan}

Metode keteladanan yang diterapkan akan berpengaruh besar pada diri anak. Namun, bisa saja di kemudian hari anak yang dididik dari keluarga yang memberikan keteladanan baik berubah menjadi anak yang tidak baik. atau sebaliknya, anak yang tidak mendapat keteladanan yang baik dapat menjadi anak yang baik. Berusaha semaksimal mungkin dan bertawakal itulah yang perlu dilakukan orang tua pada saat mendidik anak-anaknya.

Keteladanan yang ada dalam diri pendidik haruslah berkiblat pada tuntunan Allah pada kitab 
suci-Nya. Hal ini terdapat dalam QS. Al-Nahl [16]: 125

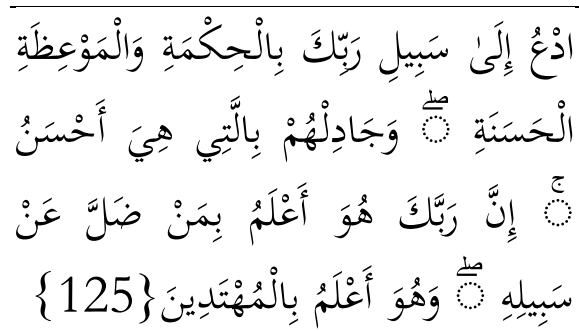
Artinya: Serulab (manusia) kepada jalan Tuhan-mu dengan bikmah dan pelajaran yang baik dan bantablah mereka dengan cara yang baik. Sesungguhnya Tuhanmu Dialah yang lebih mengetabui tentang siapa yang tersesat dari jalan-Nya dan Dialah yang lebih mengetahui orang-orang yang mendapat petunjuk.

Abdallah Yousuf memberikan tafsiran terhadap ayat ini sebagai berikut: untuk menyampaikan amanat Allah di atas pendidik harus melakukannya dengan penuh arif dan bijaksana, mendidik anak sesuai dengan pengetahuan dan kemampuan mereka. Ajaran yang diberikan harus mencerahkan, tidak dogmatik, tidak untuk kepentingan sendiri, tid- ak menghina, tetapi lembut, cermat, dan hal semacam ini akan menarik perhatian anak didik ${ }^{10}$.

\section{2) Metode Pembiasaan \\ Dalam psikologi kebiasaan} yang dilakukan secara terus menerus minimal selamaenambulan menandakan kebiasaan itu telah menjadi bagian dari karakter atau perilaku tetap anak. Anak dilahirkan dalam keadaan bersih, kedua orang tualah yang akan memberi warna dan coraknya. Oleh karena itu anak hendaklah dididik dengan pembiasan yang baik sejak dini ${ }^{11}$.

\section{3) Metode Pembinaan}

Pembinaan adalah arahan atau bimbingan yang intensif terhadap jiwa anak sehingga akan tumbuh pemahaman yang mendalam dan kesadaran untuk ber-

\footnotetext{
10 Helmawati, Pendidikan Keluar-
} ga, hlm. 60

11 Helmawati, Pendidikan Keluarga, hlm. 61 


\section{Ade Kartini, Asep Maulana}

perilaku yang sesuai dengan bimbingan yang diberikan.

Pembinaan yang dapat diberikan kepada anak di antaranya sebagai berikut: pembinaan akidah, pembinaan ibadah, pembinaan akhlak, pembinaan mental bermasyarakat (sosial), pembinaan perasaan dan kejiwaan, pembinaan kesehatan dan jasmani, pembinaan intelektual, Pembinaan etika seksual ${ }^{12}$

\section{4) Metode Kisah}

Metode kisah atau cerita mempunyai pengaruh tersendiri terhadap jiwa dan akal anak. Banyak hal positif yang dapat diperoleh dari metode kisah apalagi bila disampaikan dengan cara yang menarik. Keuntungan dari metode ini, yaitu: 1) Anak akan memiliki pengetahuan tentang sejarah; 2) Wawasan bertambah karena akal anak akan terangsang untuk bertanya; 3) Nasihat dari inti sari cerita disampaikan dengan bahasa ga, hlm. 62 yang tidak menggurui; 4) Manambah ikatan emosional yang lebih erat; 5) Jembatan komunikasi yang efektif; 6) Inspirasi dan motivasi bagi anak ${ }^{13}$

\section{5) Metode Dialog \\ Dialog merupakan suatu} metode untuk menyamakan persepsi. Dialog orang tua dan anak perlu dibangun guna menghindari konflik yang terjadi antar dua generasi yang berbeda jaman, cara pandang, memaknai hidup, dan pengalaman. Dari dialog dua arah akan diperoleh pemahamanpemahaman dan sikap saling pengertian serta menghormati perbedaan satu sama lain.

Manfaat dari dialog dalam keluarga di antaranya: 1) saling memahami dan mengerti; 2) menghindari perselisihan; 3) menambah wawasan; 4) menyadarkan pemahaman yang keliru; 5) menambah ikatan emosional. ${ }^{14}$

${ }^{13}$ Helmawati, Pendidikan Keluarga, hlm. 63

${ }^{14}$ Helmawati, Pendidikan Keluarga, hlm. 65 
Vol. 13, No. 2, Oktober 2020

p-ISSN:2086 -0749

e-ISSN:2654-4784

\section{6) Metode Ganjaran dan}

\section{Hukuman}

Orang tua sejak dini harus memberikan pemahaman bahwa setiap perbuatan akan ada konsekuensinya. Perbuatan yang baik akan menghasilkan hal yang baik dan juga sebaliknya.

7) Metode Internalisasi

Perkembangan jaman dan percepatan teknologi membuat tantangan tersendiri bagi orang tua sebagai pendidik. Anak merupakan objek empuk bagi dua hal tersebut. Pembentukan karakter dalam hal ini tidak hanya sekedar menjadi proses transformasi saja tapi diharapkan terdapat proses internalisasi. Proses tersebut bukan hanya sekedar anak jadi hanya tahu namun anak harus menjadi sosok pelaku. Hal ini diusulkan oleh Ahmad Tafsir sebagai metode mendidik. Metode internalisasi memberikan saran tentang cara mendidik agar anak beragama. Ada tiga tahapan dari pelaksanaan metode ini, yaitu learning to know, learning to do, dan learning to be. ${ }^{15}$

\section{Model Pengembangan Pen-} didikan Karakter dalam Keluarga

Perkembangan karakter pada setiap individu dipengaruhi oleh faktor bawaan (nature) dan faktor sosialisasi dan lingkungan (nurture). Menurut para ahli psikologi perkembangan setiap manusia memiliki potensi bawaan yang akan termanifestasi setelah dia dilahirkan, termasuk potensi yang terkait dengan karakter atau nilai-nilai kebaikan. Menurut Thomas Lickona pendidikan karakter perlu dilakukan sejak usia dini. ${ }^{16}$ Erik Erickson juga menga-

15 Helmawati, Pendidikan Keluarga, hlm. 69

16 Thomas Lickona, Educating for Character Mendidik Untuk Membentuk 


\section{Ade Kartini, Asep Maulana}

takan hal yang sama, bahwa anak merupakan gambaran awal manusia menjadi manusia, yaitu masa di mana kebaikan berkembang secara perlahan tapi pasti. Selanjutnya White menyatakan bahwa usia dua tahun pertama dalam kehidupan adalah masa kritis bagi pembentukan pola penyesuaian personal dan sosial. ${ }^{17}$

Dalam tataran praksis pendidikan dan pembentukan karakter dalam keluarga sebagai sebagai lembaga informal jelas berbeda dengan sekolah sebagai lembaga formal. Seperti penyelenggaraan pendidikan di lembaga formal, pendidikan dalam keluarga pun harus memiliki tujuan. Tujuan pendidikan karakter di dalam keluarga disarikan dari dalil kitab suci al-Quran dan al-Hadits sebagai pedoman hidup.
Penentuan tujuan merupakan awal dari sebuah model yang akan dikembangkan. Pendekatan model yang dipakai diadaptasi dari Basic Teaching Model yang dikembangkan oleh Robert Glaser pada tahun 1962. Model ini disebut basic karena menggambarkan seluruh proses pengajaran hanya dalam empat komponen, di mana karakter komponennya saling terkait satu sama lain dan bersifat sekuen. $^{18}$

Tujuan akan mengarahkan seluruh program dan proses pada satu arah yang jelas. Sementara proses akan mengimplementasi program yang dirumuskan dan evaluasi akan mengukur berhasil tidaknya model yang dijalankan.

Gambar 2.2

\section{Basic Model Pendidikan Karakter}

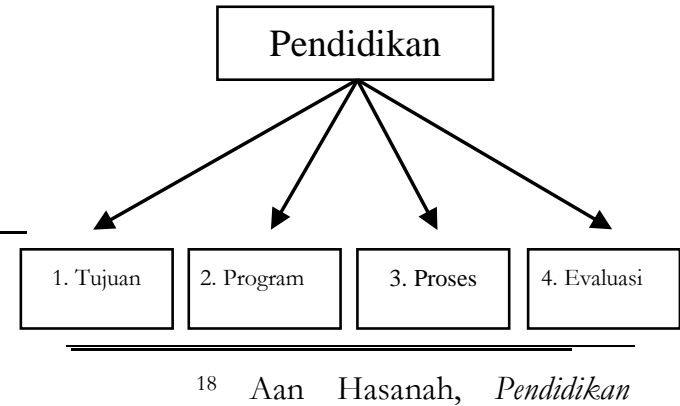

Karakter, hlm. 116

Karakter, (Jakarta: Bumi Aksara, 2012), terj., cet. IV, hlm. 555

17 Elizabeth Hurlock, Development Psycology, (Jakarta: Erlangga, 1997), terj., cet. IV, hlm. 146 
Menilik dari tujuan, maka tujuan pendidikan dalam keluarga adalah sebagai berikut:

a. Memelihara keluarga dari api neraka

Al-Tahrim [66]: 6

يَا أَيْهُها الَّذِينَ آَنْوُا قُوا أَنْفُسَكُمْ

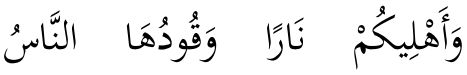

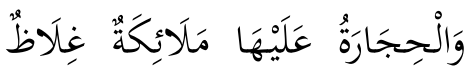

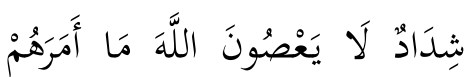

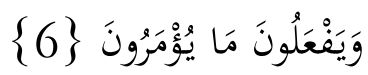

Artinya: Hai orang-orang yang beriman, peliharalah dirimu dan keluargamu dari api neraka yang bahan bakarnya adalah manusia dan batu; penjaganya malaikat-malaikat yang kasar, keras, dan tidak mendurbakai Allab terbadap apa yang diperintabkan-Nya kepada mereka dan selalu mengerjakan apa yang diperintabkan.

b. Beribadah kepada Allah SWT

Al-An'am[6]: 162

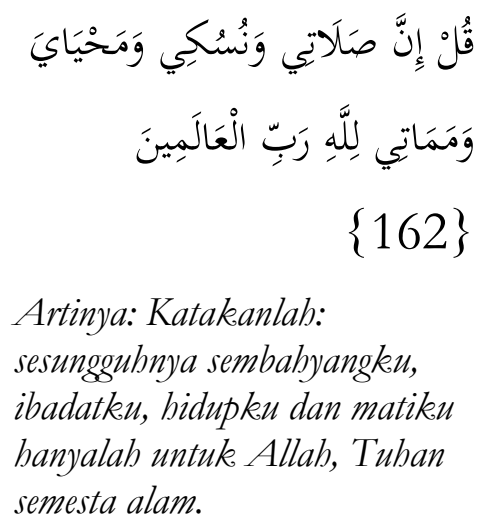

Artinya: Katakanlah: sesunggubnya sembabyangku, ibadatku, bidupku dan matiku banyalah untuk. Allah, Tuban semesta alam.

c. Membentuk akhlak mulia Luqman [31]: 12-19

وَلَقََْ آتَيْنَا لُقْمَانَ الْحِكْمَةَ أَنِ

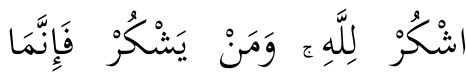

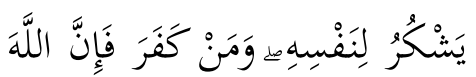
غَنْيُّ حَمِيٌُ

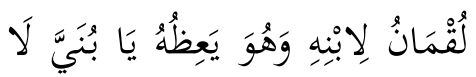
تُشُرِكْ بِاللَّهِ عَظِيمٌ $\{13$ وَوَصَّيْنَا الْإِنْسَانَ

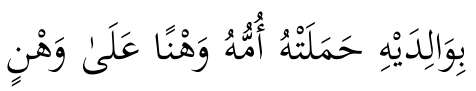
وَفِصَالُهُ فِي عَامَيْنِ أَنِ اشْكُرْ لِي وَلِوَالِدَيْكَ ع إلََيَّ الْمَصِير وَإِنْ جَاهَدَاكَ عَلَكْ أَنْ تُشْرِكَ بِي 


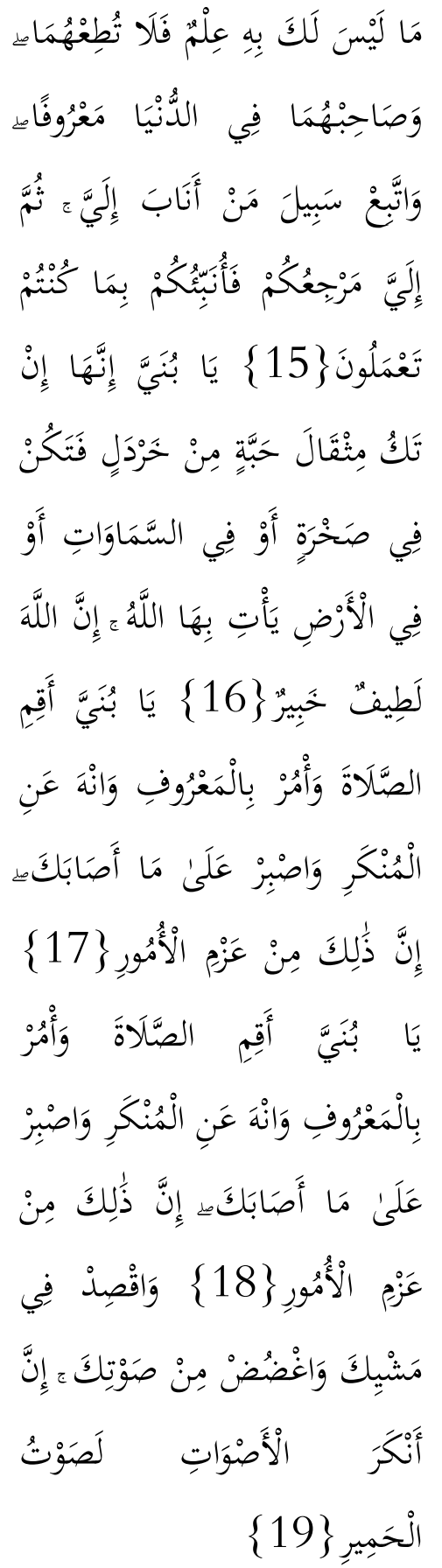

Artinya: 12. Dan sesunggubnya telah Kami berikan bikmat kepada Luqman, yaitu: "Ber- syukurlah kepada Allah. Dan barangsiapa yang bersyukur (kepada Allab), maka sesunggubnya ia bersyukur untuk dirinya sendiri; dan barangsiapa yang tidak bersyukur, maka sesunggubnya Allab Maha Kaya lagi Maba Terpuji". 13. Dan (ingatlab) ketika Luqman berkata kepada anaknya, di waktu ia memberi pelajaran kepadanya: "Hai anakku, janganlah kamu mempersekutukan Allah, sesunggubnya mempersekutukan (Allab) adalab benar-benar kezaliman yang besar". 14. Dan Kami perintabkan kepada manusia (berbuat baik) kepada dua orang ibu-bapaknya; ibunya telab mengandungnya dalam keadaan lemah yang bertambahtambah, dan menyapibnya dalam dua tabun. Bersyukurlah kepada-Ku dan kepada dua orang ibu bapakmu, hanya kepada-Kulah kembalimu. 15. Dan jika keduanya memaksamu untuk mempersekutukan dengan Aku sesuatu yang tidak ada pengetabuanmu tentang itu, maka janganlah kamu mengikuti keduanya, dan pergaulilab keduanya di dunia dengan baik, dan ikutilah jalan orang yang kembali kepada-Ku, kemudian banya kepada-Kulah kembalimu, maka Kuberitakan kepadamu apa yang telah kamu kerjakan. 16. (Luqman berkata): "Hai anakku, sesunggubnya 
jikea ada (sesuatu perbuatan) seberat biji sawi, dan berada dalam batu atau di langit atau di dalam bumi, niscaya Allah akan mendatangkannya (membalasinya). Sesunggubnya Allah Maha Halus lagi Maha Mengetabui. 17. Hai anakeku, dirikanlah shalat dan surublab (manusia) mengerjakan yang baik dan cegablab (mereka) dari perbuatan yang mungkar dan bersabarlah terhadap apa yang menimpa kamu. Sesunggubnya yang demikian itu termasuk halhal yang diwajibkan (oleh Allab). 18. Dan janganlah kamu memalingkan mukamu dari manusia (karena sombong) dan janganlab kamu berjalan di muka bumi dengan angkuh. Sesunggubnya Allah tidak menyukai orang-orang yang sombong lagi membanggakan diri. 19. Dan sederbanalah kamu dalam berjalan dan lunakkanlab suaramu. Sesunggubnya seburuk-buruk suara ialah suara keledai.

d. Membentuk anak agar kuat secara individu, sosial, dan profesional $^{19}$

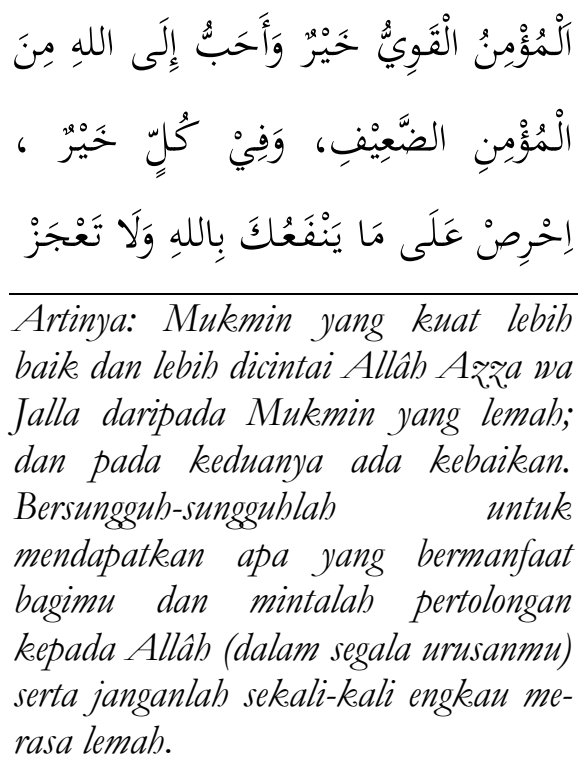

Setelah penetapan tujuan, maka disusunlah program dengan maksud untuk mencapai tujuan yang telah ditetapkan. Program harus terencana dan terukur agar pencapaian tujuan bisa maksimal dan optimal. Program yang bisa dijalankan dalam rangka menanamkan dan menumbuhkan karakter anak di dalam keluarga dengan cara sebagai berikut:

${ }^{19}$ Helmawati, Pendidikan Keluarga, hlm. 51 


\section{Ade Kartini, Asep Maulana}

1. Peneladanan

QS.Al-Ahzab [33] :21

كَقَدْ كَانَ لَكُمْ فِي رَسُولِ اللَّهِ

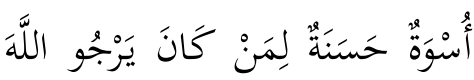

وَالْيَوْمَ الْآحِرَ وَذَكَرَ اللَّة كَثِيرًا

$\{21\}$

Artinya: Sesunggubnya telah ada pada (diri) Rasulullab itu suri teladan yang baik bagimu (yaitu) bagi orang yang mengharap (rahmat) Allah dan (kedatangan) hari kiamat dan dia banyak menyebut Allah.

\section{Pembiasaan}

QS. Al-Rum [31]: 30

فِطرَتَ اللَّهِ التَّنِي فَطَرَ النَّاسَ عَلَيْهَا

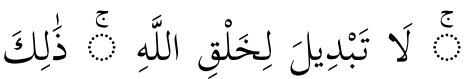

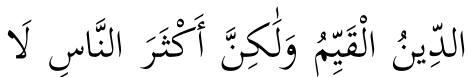
يَعْلَمُونَ 30$\}$

Artinya: (tetaplah atas) fitrah Allah yang telah menciptakan manusia menurut fitrah itu. Tidak ada peubahan pada fitrah Allah. (Itulab) agama yang lurus; tetapi kebanyakan manusia tidak mengetabui

\section{Pemberian nasihat}

QS. Al-Thalaq [65]:2

ذِلِكُمْ يُوعَظُ بِهِ مَنْ كَانَ يُؤِْْنُ

بِاللَّهِ وَالْيَوْْر الْآخِرِ $\{2$

Artinya: Demikianlah diberi pengajaran dengan itu orang yang beriman kepada Allah dan hari akbirat.

\section{Pemberian perhatian}

QS. Al-Baqarah [2]: 233

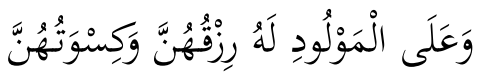

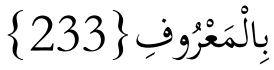

\section{Pemberian hukuman}

QS. Al-Baqarah [2]: 179

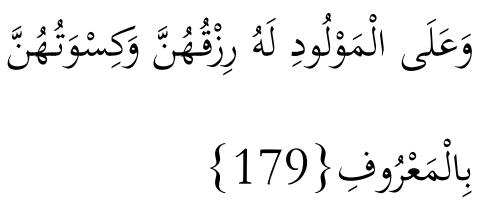

Artinya: Dan dalam qishaash itu ada (jaminan kelangsungan) bidup bagimu, hai orang-orang yang berakal, supaya kamu bertakwa. ${ }^{20}$

Proses adalah suatu kegiatan yang disengaja untuk

20 Abdullah Nashih Ulwan, Tarbiyah al-Aulad, (Jakarta: Pustaka Amani, 1995), terj., hlm 1-182 
Vol. 13, No. 2, Oktober 2020

p-ISSN:2086 -0749

e-ISSN:2654-4784

mengarahkan program agar dapat mencapai tujuan yang ditetapkan.

Aan Hasanah mencantumkan kurikulum, guru, siswa, strategi, metode, dan lingkungan sebagai komponen yang mengisi proses. ${ }^{21}$ Proses pendidikan di dalam keluarga pun mempunyai kurikulum, walau komponen lain tidak akan bisa masuk ke dalam lembaga keluarga. Paling tidak ada tiga komponen yang bisa masuk ke dalam proses ini yaitu: kurikulum, metode, dan strategi.

Kurikulum yang dapat diapliksikan di dalam pendidikan keluarga tentu berbeda dengan kurikulum yang ada di lembaga formal. Kurikulum yang bisa diadopsi untuk pendidikan karakter dalam keluarga ada dua rujukan. Konsep kurikulum pertama disusun oleh Ibnu Sina, dan kon-

21 Aan Hasanah, Pendidikan Karakter, hlm 119 sep kedua oleh al-Syaibani. ${ }^{22}$ Perumusan kurikulum kedua tokoh memang berbeda. Perbedaan hanya terletak pada pembagian materi yang akan diajarkan ke anak sesuai dengan usia dan tahap perkembangan saja. Selain hal yang telah disebut, ada beberapa hal yang sama dari kedua tokoh ini yang bisa kita berikan garis bawah, yaitu: 1) Aqidah; 2) Ibadah; 3) Akhlak; 4) Olah raga dan Kesehatan; 5) Bahasa; dan 6) Kesenian.

Dalam proses pendidikan keluarga pun terdapat metode. Beberapa metode telah dicantumkan di atas sebelum tulisan ini. Metode sebelumnya adalah metode pendidikan keluarga secara umum. Metode yang dimaksud dalam bagian ini adalah metode aplikatif yang fokus lang-

${ }^{22}$ Helmawati, Pendidikan Keluarga, hlm. 54-56 


\section{Ade Kartini, Asep Maulana}

sung ke arah pembentukan karakter anak. Helmawati menulis ada enam metode yang langsung aplikatif untuk hal ini yaitu: 1) Metode Keteladanan, 2) Metode Percontohan, 3) Metode Pembiasaan, 4) Metode Pengulangan, 5) Metode Pelatihan, 6) Metode Motivasi. $^{23}$

Komponen ketiga dari proses adalah strategi. Strategi yang digunakan pada pendidikan karakter dalam keluarga bisa terpadu dalam konsep kurikulum dan metode. Maksud hal tersebut adalah penetapan strategi sebetulnya ada dalam konsep kurikulum dan metode itu sendiri. Untuk kejelasan bisa diurai sebagai berikut:

a) Pemberian perlakuan pen-

didikan karakter disesuaikan dengan tingkat perkembangan usia anak.

Pernyataan ini ada dalam konsep kurikulum Ibnu Sina dan

23 Helmawati, Pendidikan Keluarga, hlm. 166-169
al-Syaibani. Jika Ibnu Sina membagi strategi pendidikannya menjadi tiga tingkatan menurut usia, sedangkan al-Syaibani membaginya dengan istilah kurikulum tahap pertama dan kurikulum tahap akhir. ${ }^{24}$

b) Penetapan potensi perlakuan pendidikan karakter terhadap anak.

Dalam proses pendidikan perlu menghadapi dua potensi yang terdapat dalam diri anak, yaitu potensi positif dan negatif. Dari dua potensi inilah ditetapkan strategi pendidikan kerakter. Pertama, perlakuan yang bersifat positif. Kedua,a) perlakuan yang bersifat penjagaan (preventif).

Mendidik bersifat positif berarti berpusat pada dasar-dasar yang kuat dan sesuai dengan akhlak mulia dan bertujuan menanamkan kemuliaan. Seperti menanamkan keimanan dan ketakwaan. Adapun mendidik

${ }^{24}$ Helmawati, Pendidikan Keluarga, hlm. 54-56 
yang bersifat penjagaan artinya menghindarkan anak dari segala macam keburukan, baik individual maupun sosial. ${ }^{25}$

Langkah terakhir dari suatu model adalah evaluasi. Evaluasi yang dimaksud di sini adalah untuk mengukur efektivitas pelaksanaan penerapan model. Langkah evaluasi pendidikan di dalam keluarga tentu berbeda dengan evaluasi yang dilakukan sekolah formal. Bentuk evaluasi pendidikan karakter dalam keluarga dilihat dari performance. Performance sendiri merupakan bentuk evaluasi di lembaga formal, perbedaan terletak pada jangka waktu pemberian evaluasi. Maksud hal ini bila di lembaga formal evaluasi dilakukan pada waktu yang ditentukan, bila di dalam keluarga evaluasi dilakukan orang tua secara ga, hlm. 59

${ }^{25}$ Helmawati, Pendidikan Keluar- random tak terlepas dari batasan waktu. Dalam evaluasi inilah reward dan punishment bisa dimunculkan sebagai bentuk evaluasi.

Dari paparan di atas mengenai model pengembangan pendidikan karakter dalam keluarga, didapatlah sebuah model di bawah ini:

Gambar 2.3

Model pengembangan pendidikan karakter dalam keluarga

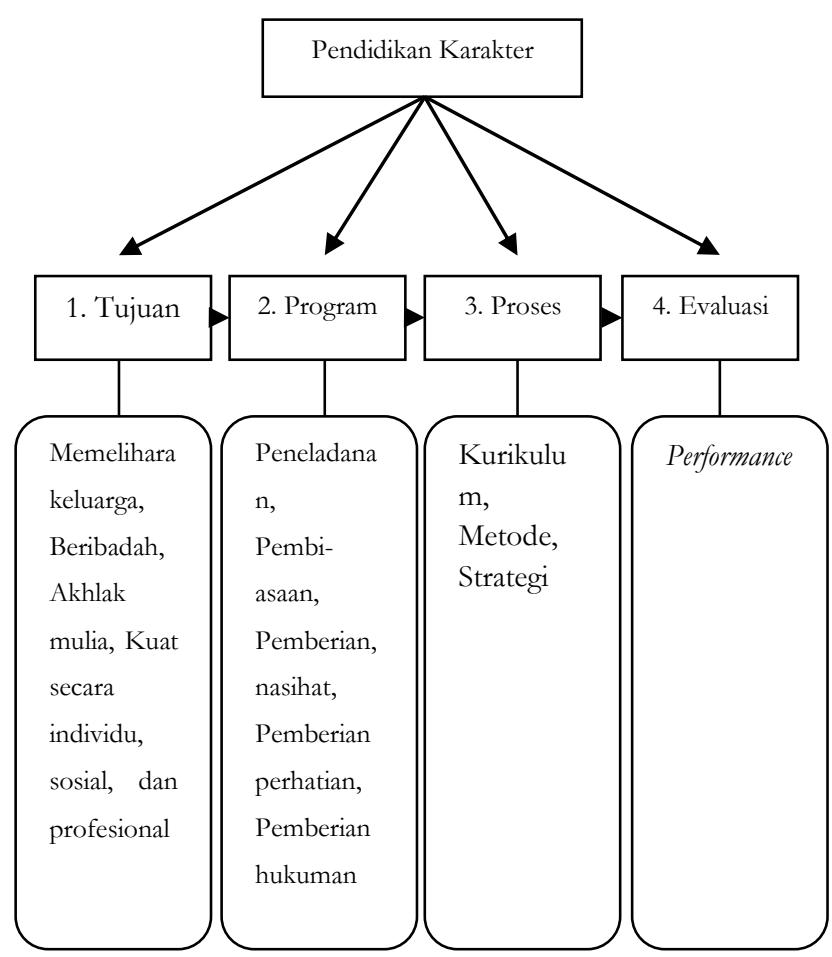




\section{Simpulan}

Karakter itu perlu dibangun, dibentuk, ditempa, dan dikembangkan serta dimantapkan. Karakter sangat dipengaruhi oleh kondisi lingkungan, baik lingkungan kecil di rumah, di masyarakat, dan selanjutnya meluas di kehidupan berbangsa dan bernegara bahkan di kehidupan global. Keluarga merupakan peran utama dalam menanamkan karakter kepada anak. Hal ini merupakan sebuah konsekuensi kausalitas dan sunnah Allah yang tak bisa dielakkan.

Seorang anak akan menjadi baik jika dididik dengan cara yang baik pula. Begitu pun sebaliknya jika dididik dengan cara yang kurang baik maka anak akan menjadi tidak baik. Pendidikan karakter yang mempunyai nilai yang luhur haruslah dirancang dalam sebuah model pendidikan. Penetapan tujuan adalah hal pertama yang harus dilakukan. Tujuan ini yang akan menuntun ke mana program ini diarahkan. Untuk memenuhi hal tersebut dibuatlah sebuah model pengembangan pendidikan karakter dalam keluarga.

Melalui beberapa pendekatan, metode, dan strategi yang telah dipaparkan diharapkan model bisa menjadi salah satu acuan dalam program pendidikan karakter dalam keluarga. Harapan semoga keluarga Indonesia bisa menjadi embrio tumbuhnya generasi berkarakter di masa yang akan datang yang mampu merubah wajah dunia menjadi lebih indah dan damai.

Model pengembangan yang dipaparkan tentu masih jauh dari kata sempurna. Harapan bagi praktisi dan pemerhati pendidikan agar dapat menyempurnakan model ini dengan lebih baik dan sempurna. Penambahan komponen masih bisa ditambahkan dalam model tersebut. 


\section{Daftar Pustaka}

Adhim, Mohammad Fauzil. 2015. Positive Parenting. Yogyakarta: Pro U-Media.

Aqib, Zainal. 2014. Pendidikan Karakter Membangun Perilaku Positif Anak Bangsa. Bandung: Yrama Widya.

Hasanah, Aan. 2013. Pendidikan Karakter Berperspektif Islam. Bandung: Insan Komunika.

Helmawati. 2014. Pendidikan Keluarga Teoritis dan Praktis. Bandung: Remaja Rosdakarya.

Hurlock, Elizabeth. 1997. Development Psycology. terj. Jakarta: Erlangga.

Lickona, Thomas. 2012. Educating for Character Mendidik Untuk. Membentuk Karakter. terj. Jakarta: Bumi Aksara.

Muslich, Masnur. 2014. Pendidikan Karakter Menjawab Tantangan Krisis Multidimensional. Jakarta: Bumi Aksara.

Sani, Ridwan Abdullah dan $\mathrm{Mu}-$ hammad Kadri. 2016. Pendidikan Karakter Mengem- bangkan Karakter Anak yang Islami. Jakarta: Bumi Aksara.

Ulwan, Abdullah Nashih. 1995. Tarbiyah al-Aulad. terj. Jakarta: Pustaka Amani.

\section{http://tafsirq.com/en}

http://www.mutiarahadits.com/7 2/68/76/makna-setiap-anakterlahir-dalam- keadaan-fitrah.htm

https://almanhaj.or.id/3841mukmin-yang-kuat-lebih-baikdan-lebih-dicintai- oleh- allah-subhanahu-wa-taala.html 